\title{
Edukasi Dengan Metode Audiovisual Sebagai Upaya Peningkatan Pengetahuan Kader Mengenai Bahaya Tersedak Pada Bayi
}

\author{
Noerma Shovie Rizqiea ${ }^{*}$, Ratih Dwilestari Puji Utami ${ }^{2}$ \\ ${ }^{1,2}$ Universitas Kusuma Husada Surakarta \\ *Email: noerma.shovie@ukh.ac.id
}

\begin{abstract}
Background: Children are uniquely vulnerable to a variety of emergency situations. These situations are often life-threatening if not treated quickly and effectively. Infants and young children are at higher risk for respiratory emergencies than adolescents or adults. Young children often lack coordination, which makes them prone to choking on food and small objects, which can also lead to cardiac arrest. The aim of this community service is that after receiving health education and demonstrations about the dangers of choking, it hopes that an increase in cadres' knowledge of the dangers of choking at the Posyandu for toddlers, Sadar Ibu I, Dusun Jetak. Methods: Respondents involved were 14 cadres of Posyandu Toddler Sadar Ibu I Dusun Jetak. Activities carried out online. The activity began with a pre-test, then continued with provisions health education using audio-visual video media, and ended with a post-test measurement. Results: The percentage of knowledge of cadres during the pre-test showed that 3 cadres (21\%) had good knowledge, and the remaining 11 cadres (79\%) had less knowledge. The post-test results showed that 10 cadres (71\%) had good knowledge, and the remaining 4 cadres (29\%) still had a bad knowledge. Conclusion: Increase Cadre's knowledge of the dangers of choking on babies.
\end{abstract}

Keywords: babies, cadre's knowledge, choking hazards

\section{PENDAHULUAN}

Anak secara unik rentan terhadap berbagai situasi kedaruratan. Situasi ini sering kali mengancam jiwa jika tidak ditangani secara cepat dan efektif. Bayi dan anak kecil berisiko lebih tinggi untuk mengalami kedaruratan pernafasan dibandingkan dengan remaja ataupun orang dewasa. Anak kecil sering kali kurang koordinasi sehingga membuat mereka rentan tersedak makanan dan benda kecil, yang juga dapat menyebabkaan mereka henti jantung paru (Kyle, T., \& Carman, 2014).

Tersedak terjadi ketika makanan atau benda kecil tersangkut di tenggorokan dan memblok jalan nafas. Hal ini dapat mengakibatkan oksigen tidak dapat mengalir ke paru-paru dan otak. Ketika otak tidak teroksigenasi lebih dari 4 menit, maka bisa terjadi kerusakan otak bahkan kematian. Setiap tahunnya, terdapat kematian anak yang disebabkan oleh tersedak. Beberapa anak yang meninggal karena tersedak, berusia kurang dari 5 tahun. Selain itu, tersedak juga menyebabkan kematian sebanyak 2/3 kematian bayi berusia kurang dari 1 tahun (Cpr, 2006).

Tersedak bisa juga terjadi akibat tehnik menyusui yang tidak tepat. Hal ini bisa terjadi ketika payudara telalu menekan sehingga dapat menyumbat pernafasan bayi dan membuat bayi tersedak. Setelah menyusui, ibu boleh meluruskan bayi dalam dekapan dengan posisi tegak lurus sejajar dengan tubuh ibu dan kepala berasa di pundak. Kemudian punggung bayi ditepuk secara perlahanlahan sampai kemudian ia bersendawa dan keluar angin dari mulutnya (Darmawati, 2013). 
Penelitian yang dilakukan di Puskesmas Ranotana Weru Kecamatan Wanea Kota Manado pada 16 ibu-ibu menyusui yang menjadi responden. Diperoleh hasil adanya pengaruh penyuluhan kesehatan tentang penanganan tersedak terhadap pengetahuan ibu menyusui di Puskesmas Ranotana Weu. Tingkat pengetahuan ibuibu menyusui berubah ketika pre test dan post test, yaitu 93,8\% ibu-ibu memiliki pengetahuan cukup (pre test) menjadi 100\% ibu-ibu menyusui memiiki pengetahuan baik (post test) (Pandegirot \& Masi, 2019).

Penelitian lain yang dilakukan pada 33 siswa kelas 6 SD, setelah diberikan pendidikan kesehatan selama 40 menit menggunakan media video dan leaflet, diperoleh hasil sebanyak $90 \%$ siswa mengerti tentang pengertian tersedak, $90 \%$ siswa mengerti tentang tanda-tanda tersedak, $70 \%$ siswa dapat menirukan cara pemberian pertolongan pertama orang tersedak, dan $95 \%$ siswa mengerti cara pencegahan tersedak (Riesmiyatiningdyah et al., 2019).

Hasil wawancara dengan kader Posyandu balita Sadar Ibu I Dusun Jetak diperoleh bahwa disana belum pernah mendapat pengetahuan mengenai tersedak, terutama untuk balita. Adanya pernyataan tersebut, membuat penulis tergugah untuk mengajarkan lebih lanjut pada kader Posyandu mengenai pencegahan dan penanganan tersedak pada balita. Ulasan tersebut menguatkan pentingnya pengabdian masyarakat "Upaya Peningkatan Pengetahuan Kader mengenai Bahaya Tersedak pada Balita di Posyandu Balita Sadar Ibu I Dusun Jetak, Kelurahan Wonorejo, Kecamatan Gondangrejo, Kabupaten Karanganyar.”

\section{TINJAUAN PUSTAKA}

Tersedak terjadi akibat benda kecil, mainan atau sepotong makanan yang menghalangi jalan napas. Bayi dan anak-anak kecil memiliki saluran udara yang sangat kecil sehingga membuat mereka lebih mudah untuk tersedak (Bull, 2018). Anak kecil lebih berisiko tersedak karena sesuai dengan tahapan perkembangan yang masih mengeksplor lingkungan dan objek baru dengan menggunakan mulut. Anak dengan usia yang lebih kecil juga mudah teralihkan sehingga mereka dapat makan dengan berlari, tertawa, dan berbicara sehingga meningkatkan risiko terjadinya tersedak (Denny et al., 2015).

Anatomi pada anak usia dibawah 1 tahun, kepala anak lebih besar daripada tubuhnya dan ketika berbaring leher anak akan tertekuk ketika di permukaan yang datar, pada anak lidahnya lebih besar dan rahang bawahnya lebih pendek. Hal tersebut meningkatkan risiko tertutupnya jalan napas pada anak (DeMasie, 2013). Perbedaan posisi menyusui juga menjadi salah satu yang dapat mempengaruhi pengalaman tersedak pada bayi. Hasil penelitian sebelumnya didapatkan bahwa pengalaman Ibu yang dibedakan dalam 3 posisi saat menyusui, yaitu posisi berdiri, duduk, dan berbaring didapatkan paling tinggi bayi mengalami tersedak pada posisi berbaring, yaitu sebesar 51\% (Pirantika, A. Purwanti, 2017).

Pertolongan pertama bayi yang mengalami tersedak adalah dengan memberikan kombinasi antara 5 kali back blows yang juga disertai dengan 5 kali chest thrusts. Kombinasi dua tindakan tersebut diberikan hingga bayi dapat menangis dengan keras atau bernafas atau menjadi tidak responsif. Bayi tetap harus dievaluasi 
walaupun kejadian tersedak sudah selesai, untuk memastikan tidak ada kerusakan jalan nafas. Posisi penolong selama memberikan pertolongan bayi yang tersedak adalah dengan posisi duduk, berlutut, ataupun berdiri selama penolong dapat menopang kepala bayi. Posisi kepala bayi harus lebih rendah dari dada. Pertahankan kepala dan leher bayi dengan kuat menggunakan lengan penolong dan diletakkan diantara jempol dan jari telunjuk (Alton L. Thygerson \& M.D. Gulli, 2006), dan (Participants Manual Fully Revised October 2015.Pdf, n.d.).
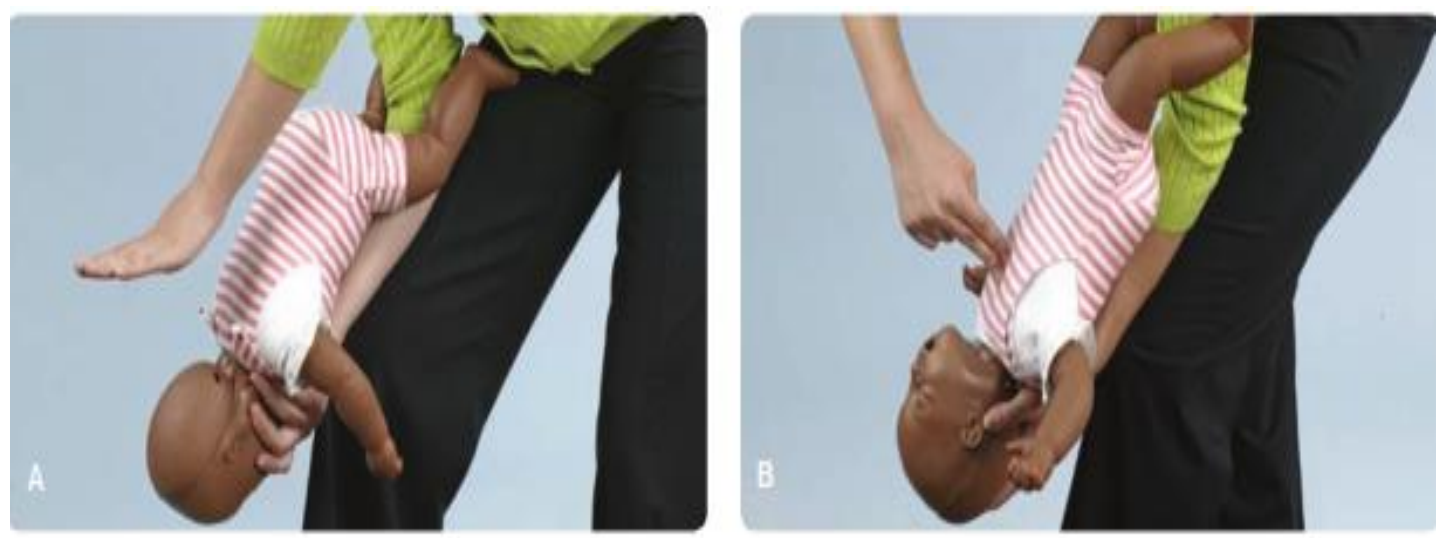

Gambar 1. Kombinasi back blows (A) dengan chest thrusts (B) (Alton L. Thygerson \& M.D. Gulli, 2006)

\section{METODE}

Pelaksanaan kegiatan pengabdian kepada masyarakat dilakukan secara daring karena masih dalam masa pandemi COVID-19 dan Posyandu belum aktif kembali. Sebelumnya, untuk memudahkan pelaksanaan kegiatan pengabdian kepada masyarakat, penulis telah membuat grup whatsapp bersama dengan 14 kader Posyandu Balita Sadar Ibu I Dusun Jetak. Kegiatan daring dilakukan pada hari Rabu, 5 Agustus 2020. Pelaksanaan kegiatan diawali dengan pre-test, kemudian dilanjutkan dengan pemberian pendidikan kesehatan menggunakan media audio visual video, dan diakhiri dengan pengukuran post-test. Pre-test dan post-test juga dilakukan secara daring dengan menggunakan bantuan aplikasi jotform mobile forms \& surveys. Pemberian video tentang bahaya tersedak diberikan melalui aplikasi whatsapp messenger. Kegiatan ini dilakukan dengan metode ceramah, demonstrasi, dan tanya jawab. Ceramah dan demonstrasi menjadi satu video penjelasan yang dibuat sendiri oleh pennulis menggunakan canva. Kemudian sesi diskusi berupa tanya jawab, dilakukan penulis melalui video call dan chat grup whatsapp.

Video berisi tentang pengertian tersedak, penyebab terjadinya tersedak, mengenali tanda-tanda tersedak, pencegahan tersedak, dan juga demonstrasi pemberian pertolongan pertama jika bayi tersedak. Selain memberikan video sebagai media edukasi, penulis juga memberikan leaflet yang diberikan supaya dapat dibaca ulang oleh kader, dan dapat diberikan kepada Ibu peserta Posyandu (jika Posyandu sudah aktif kembali). 


\section{HASIL}

Program peningkatan pengetahuan ini diawali dengan pre test untuk menggali pengetahuan kader mengenai pengertian, penyebab, tanda-tanda, pencegahan, dan pertolongan pertama pada bayi tersedak. Persentase pengetahuan kader saat pre-test diperoleh hasil 3 kader (21\%) memiliki pengetahuan baik, dan sisanya sebanyak 11 kader $(79 \%)$ memiliki pengetahuan kurang. Mayoritas kesalahan jawaban kader pada pertanyaan nomor 5 mengenai pertolongan pertama bayi tersedak. Post test dilakukan setelah pemaparan video bahaya tersedak pada bayi dan setelah sesi tanya jawab. Hasil post test didapatkan 10 kader (71\%) memiliki pengetahuan baik, karena mampu menjawab 5 pertanyaan tentang bahaya tersedak pada balita dengan benar. Sisanya, sebanyak 4 kader (29\%) masih memiliki pengetahuan buruk, karena belum mampu menjawab 5 pertanyaan dengan benar.

\section{PEMBAHASAN}

Pelaksanaan kegiatan pengabdian kepada masyarakat dilakukan secara daring karena masih dalam masa pandemi COVID-19 dan Posyandu belum aktif kembali. Pelaksanaan kegiatan diawali dengan pre-test, kemudian dilanjutkan dengan pemberian pendidikan kesehatan menggunakan media audio visual video, dan diakhiri dengan pengukuran post-test. Pre-test dan post-test juga dilakukan secara daring dengan menggunakan bantuan aplikasi jotform mobile forms \& surveys. Pemberian video tentang bahaya tersedak diberikan melalui aplikasi whatsapp messenger. Kegiatan ini dilakukan dengan metode ceramah, demonstrasi, dan tanya jawab. Ceramah dan demonstrasi menjadi satu video penjelasan yang dibuat sendiri oleh penulis menggunakan canva. Kemudian sesi diskusi berupa tanya jawab, dilakukan penulis melalui video call dan chat grup whatsapp.

Perubahan pola pembelajaran di masa pandemi COVID-19 sehingga mewajibkan pendidik menerapkan belajar secara online/daring. Salah satu pembelajaran online yang dapat diterapkan adalah dengan pemberian materi pembelajaran melalui video pembelajaran (Abidin et al., 2020). Penelitian lain dari (Sukardi \& Rozi, 2019) didapatkan bahwa pembelajaran dengan blanded learning lebih efektif dari conventional learning karena peserta didik dapat bertanya melalui chat online. Selain itu, hal tersebut juga dianggap memberikan kemudahan untuk peserta didik karena mereka dapat melakukan aktivitas belajar dimana saja, kapan saja dan tanpa terbatas ruang dan waktu.

Kader menjadi responden dalam pemberian pendidikan kesehatan mengenai bahaya tersedak. Persentase pengetahuan kader saat pre-test diperoleh hasil 3 kader (21\%) memiliki pengetahuan baik, dan sisanya sebanyak 11 kader (79\%) memiliki pengetahuan kurang. Mayoritas kesalahan jawaban kader pada pertanyaan nomor 5 mengenai pertolongan pertama bayi tersedak. Post test dilakukan setelah pemaparan video bahaya tersedak pada bayi dan setelah sesi tanya jawab. Hasil post test didapatkan 10 kader (71\%) memiliki pengetahuan baik, karena mampu menjawab 5 pertanyaan tentang bahaya tersedak pada balita dengan benar. Sisanya, sebanyak 4 kader (29\%) masih memiliki pengetahuan buruk, karena belum mampu menjawab 5 pertanyaan dengan benar. Dengan meningkatnya pengetahuan mengenai bahaya 
tersedak pada kader, besar harapan penulis di pertemuan berikutnya, kader dapat melanjutkan informasi mengenai bahaya tersedak kepada ibu peserta Posyandu Balita dengan tujuan untuk mencegah terjadinya tersedak pada bayi terutama ketika ibu menyusui.

Penelitian dari (Pandegirot\&Masi,2019) menyampaikan pentingnya penyuluhan kesehatan mengenai penanganan tersedak terhadap pengetahuan ibu menyusui. Hal yang mendasari penelitian adalah untuk mengurangi kematian bayi akibat tersedak. Penyuluhan yang dilakukan menggunakan leaflet karena untuk menghindari kesalahan persepsi, memperjelas informasi, dan mempermudah pengertian. Penelitian lain dari (Fatimah et al., 2019) setelah mendapatkan edukasi menggunakan video didapatkan hasil adanya peningkatan pengetahuan mengenai Program Gerakan Satu Rumah Satu Jumantik (G1R1J) yaitu pengetahuan baik dari $46,9 \%$ menjadi $57,1 \%$, dan pengetahuan kurang baik dari $53,1 \%$ menjadi $42,9 \%$. Kedua penelitian di atas menunjukkan bahwa kedua media tersebut sama-sama berpengaruh dalam merubah pengetahuan masyarakat.

\section{KESIMPULAN DAN SARAN}

\section{a. Kesimpulan}

Pemberian pendidikan kesehatan dan demontrasi mengenai pengertian, penyebab, tanda-tanda, pencegahan dan pertolongan pertama pada bayi tersedak sangat membantu kader dalam meningkatkan pengetahuan kader dari $21 \%$ menjadi $71 \%$ yang berpengetahuan baik, dan menurunkan pengetahuan kader dari $79 \%$ menjadi $29 \%$ yang berpengetahuan buruk.

\section{b. Saran}

Kader memiliki kewajiban menyampaikan informasi baik dalam bentuk media cetak (leaflet) ataupun audiovisual (video) yang bermanfaat kepada ibu peserta Posyandu terutama masalah tersedak. Hal tersebut wajib disampaikan kepada ibu peserta Posyandu supaya tidak terjadi kematian bayi akibat tersedak di wilayah Posyandu Sadar Ibu I Dusun Jetak.

\section{UCAPAN TERIMA KASIH}

Ucapan terimakasih kami haturkan kepada pihak-pihak terkait yang telah membantu pelaksanaan pengabdian kepada masyarakat. Adapun pihak-pihak terkait tersebut adalah Universitas Kusuma Husada Surakarta, khususnya LPPM dan kader Posyandu Balita Sadar Ibu I Dusun Jetak.

\section{DAFTAR RUJUKAN}

Abidin, Z., Rumansyah, \& Arizona, K. (2020). Pembelajaran Online Berbasis Proyek Salah Satu Solusi Kegiatan Belajar Mengajar di Tengah Pandemi Covid-19. Jurnal Ilmiah Profesi Pendidikan, 5(1), 64-70. https://doi.org/10.29303/jipp.v5i1.111

Alton L. Thygerson, \& M.D. Gulli, B. (2006). First Aid, CPR, AED. 
Bull, T. (2018). Community Education. Developing Environmental Education In The Curriculum, 8, 132-135. https://doi.org/10.2307/3562904

Cpr, L. (2006). Choking Prevention and First Aid for Infants and Children.

Darmawati. (2013). Hubungan Faktor-Faktor Indikator Menyusui dengan Angka Kesakitan Bayi di Aceh Besar The Relationship of Breastfeeding Factors with the Baby's Morbidity in Aceh Besar Darmawati. Idea Nursing Journal, IV, 112. http://www.jurnal.unsyiah.ac.id/INJ/article/view/1598/1479

DeMasie, K. M. (2013). Pediatric Airway Management. Handbook of Pediatric Surgical Patient Care, 4(1), 71-81. https://doi.org/10.1142/9789814287890_0008

Denny, S. A., Hodges, N. L., \& Smith, G. A. (2015). Choking in the Pediatric Population. American Journal of Lifestyle Medicine, 9(6), 438-441. https://doi.org/10.1177/1559827614554901

Fatimah, F., Widyastutik, O., \& Suwarni, L. (2019). Efektivitas Media Audiovisual (Video) Terhadap Peningkatan Pengetahuan dan Sikap Kelompok Masyarakat Tentang Program G1R1J. Jurnal Kesmas (Kesehatan Masyarakat) Khatulistiwa, 6(2), 44. https://doi.org/10.29406/jkmk.v6i2.1767

Kyle, T., \& Carman, S. (2014). Buku Ajar Keperawatan Pediatri: Landasan Keperawatan Pediatri, Promosi Kesehatan, Asuhan Anak dan Keluarga (1) (2nd ed.). EGC.

Pandegirot, J. S., \& Masi, G. N. M. (2019). TE Terhadap Pengetahuan Ibu Menyusui. 7(November), 2-7.

Participants Manual Fully Revised October 2015.pdf. (n.d.).

Pirantika, A. Purwanti, R. S. (2017). Hubungan Posisi Menyusui dengan Kejadian Tersedak pada Bayi di Puskesmas Bahu Kota Manado. Universitas Nusantara PGRI Kediri, 01, 1-7. http://www.albayan.ae

Riesmiyatiningdyah, R., Nurinah, N., Santika, N. D. B., Alviana, E. W., Lerebulan, A. M., \& Sari, W. P. (2019). Improved Knowledge of First Aid in Choke. Community Service Journal of Indonesia, 1(2), 28. https://doi.org/10.36720/csji.v1i2.135

Sukardi, S., \& Rozi, F. (2019). Pengaruh Model Pembelajaran Online dilengkapi dengan Tutorial Terhadap Hasil Belajar. JIPI (Jurnal Ilmiah Penelitian dan Pembelajaran Informatika), 4(2), 97. https://doi.org/10.29100/jipi.v4i2.1066 